\author{
Mehmet Ali Erdoğan \\ Mustafa Said Aydoğan \\ Ülkü Özgül \\ Hüseyin Konur \\ Duygu Demiröz \\ Ender Gedik \\ Turkan Togal
}

\section{Sezaryen Sonrası Eklampsiyle İlişkili Ani Görme Kaybi: Olgu Sunumu}

\author{
Sudden Loss of Vision Associated with Eclampsia \\ After Caesarean Section: A Case Report
}

Geliș Tarihi/Received: 04.12.2012

Kabul Tarihi/Accepted: 14.03.2013

Türk Yoğun Bakım Derneği Dergisi, Galenos Yayınevi tarafından basılmıştır.

Journal of the Turkish Society of Intensive Care, published by Galenos Publishing.

ISNN: 1300-5804

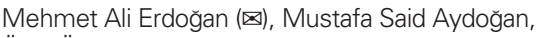
Ülkü Özgül, Hüseyin Konur, Duygu Demiröz, Ender Gedik, Turkan Togal

Inönü Üniversitesi Tıp Fakültesi, Anaestezi ve Reanimasyon Anabilim Dalı, Malatya, Türkiye

E-posta: drmalierdogan@gmail.com

Tel.: +90 4223410660
ÖZET Preeklampsi; gebeliğin ikinci yarısından sonra görülen, hipertansiyon ve proteinüri ile karakterize gebeliğe özgü bir bozukluktur. Tonik-klonik nöbet oluşturarak beynin etkilenmesiyle eklampsi formu oluşur. Eklampsi hafif preeklampsilerin \%0.5'inde, ağır preeklampsilerin ise \%2 ile \%3'ünde görülmektedir. Preeklampsi ve eklampsi görmede azalma, fotopsi ve görme alanı defektleri gibi semptomları oluşmaktadır. Şiddetli preeklampside gebelerin \%25'inde görme bozuklukları meydana gelirken, eklampside gebelerin \%1 ile \%2'sinde körlük bildirilmiştir ve nerdeyse tamamında geçici bir fenomendir. Ani görme bozukluğu veya körlük önceden sağlıkı olan bir birey için oldukça korkutucu ve endişe vericidir. Neyse ki klinik (fetusun ve plesantanın doğurtulması gibi) ve laboratuar değerlerin düzeltilmesiyle günler içinde tamamen iyileşmektedir. Titiz bir öykü ile nörolojik ve oftalmik muayene, hasta ve yakınlarına pozitif destek ile güven verilmesi büyük önem taşmaktadır. Bu sunumda, eklampsi nedeniyle acil sezaryen yapılan, bilateral kortikal görme kaybı olan olgunun yoğun bakımdaki klinik seyrini sunmayı amaçladık.

Anahtar Kelimeler: Eklampsi, kortikal körlük, gebe
SUMMARY Preeclampsia is a pregnancyspecific disorder, characterized by hypertension and proteinuria and occurring after the second half of pregnancy. When the brain was affected by tonic-clonic seizures, a form of eclampsia occurs. Eclampsia occurs in approximately $0.5 \%$ of women with mild preeclampsia and in approximately $2 \%$ to $3 \%$ of those with severe preeclampsia. Visual symptoms of preeclampsia and eclampsia include decreased vision, photopsia, and visual field defects. Visual disturbances occur in an estimated $25 \%$ of patients with severe preeclampsia. Blindness, however, is reported in only $1 \%$ to $2 \%$ of eclamptic women, and is almost exclusively a temporary phenomenon. Sudden visual impairment or total blindness is a frightening and terrifying experience in a previously healthy person. Fortunately, it almost always resolves, as do the other laboratory and clinical indices within days after removal of the fetus and placenta. A careful history, neurological and ophthalmic examination, and to be positively supported the patient and the relatives are great importance. In this presentation,we aimed to present the clinical course of the patient with bilateral cortical visual loss, who was operated an emergency Cesarean section due to eclampsia.

Key Words: Eclampsia, cortical blindness, pregnancy. 


\section{Giriş}

Preeklampsi; gebeliğin ikinci yarısından sonra görülen, hipertansiyon ve proteinüri ile karakterize gebeliğe özgü bir bozukluktur. Tüm dünyada maternal ile fetal mortalite ve morbiditenin birincil nedenidir ve gebelerin \%5 ile \%7'sini etkilemektedir $(1,2)$. Patofizyolojisi tam olarak bilinmese de azalmıs organ perfüzyonu ve endotelyal disfonksiyon suçlanmaktadır (3). Tonik-klonik nöbet oluşturarak beynin etkilenmesiyle eklampsi formu oluşur. Eklemsi hafif preeklampsilerin $\% 0.5^{\prime}$ inde, ağır preeklampsilerin ise \%2 ile \%3'ünde görülmektedir (4).

Gebelik diyabetik koriyoretinopati ve üveit gibi önceden var olan oküler durumu kötüleştirebilir, gebeliğin indüklediği hipertansiyonla ilişkili olarak kortikal körlük veya santral seröz retinopati oluşturabilir. Preeklampsi ve eklampsi görmede azalma, fotopsi ve görme alanı defektleri gibi semptomları oluşmaktadır (5). Şiddetli preeklampside gebelerin \% 25 'inde görme bozuklukları meydana gelirken, eklampside gebelerin $\% 1$ ile \%2'sinde körlük bildirilmiştir ve nerdeyse tamamında geçici bir fenomendir (6).

Kan basıncının kontrolü ve antiödem tedavi ile semptomları gerileyen hasta, hasta yakınları ve hekimler için endişe verici bir deneyim olan kortikal görme kaybının tanısının hızlı bir şekilde konulması klinik açıdan önemlidir.

Bu sunumda, eklampsi nedeniyle acil sezaryen yapılan, bilateral kortikal görme kaybı olan olgunun yoğun bakımdaki klinik seyrini sunmayı amaçladık.

\section{Olgu}

38 yaşında, primigravid ve son adet tarihine göre 34 gebelik haftasında olan hasta eklampsi ve fetal distres nedeni ile acil sezaryen sonrası entübe olarak yoğun bakım ünitemize alındı. Son 2 haftadır hipertansiyonu, pretibial ödemi ve frontal baş ağrısı olduğu ancak herhangi bir görme problemi öyküsü olmadığı öğrenildi.

Anestezi yönetiminde; tonik-klonik nöbet geçiren hastaya operasyon odasında standart monitörizasyon (noninvazif kan basıncı, kalp hızı, SpO2) yapıldı. Kalp hızı 120 atım/dakika, noninvazif kan basıncı (NIKB) 165/95 mm/Hg, SpO2 \%98 olarak ölçüldü. Preoperatif olarak başlanan $2 \mathrm{~g} / \mathrm{saat}$ intravenöz magnezyum sülfata (MgSO4) devam edildi. Genel anestezi uygulanmasına karar verildi. Preoksijenizasyon sırasında 30 sn süreyle $0.5 \mu \mathrm{g} / \mathrm{kg}$ remifentanil infüzyonu yapıldıktan sonra, tiyopental $4 \mathrm{mg} / \mathrm{kg}, 1,5 \mathrm{mg} / \mathrm{kg}$ süksinilkolin ile krikoid bası uygulayarak hızı seri indüksiyon yapıldı. Anestezi idamesinde bebek çıkana kadar \%1 sevofluran, \%50 O2/Hava karışımı ile bebek çıktıktan sonra ise \%1,5 sevofluran, \%50 O2/Hava ve $0,1 \mu \mathrm{g} / \mathrm{kg} / \mathrm{dk}$ remifentanil infüzyonu yapıldı. $2100 \mathrm{~g}$ olarak doğan kız bebeğin 1. ve 5. dk Apgar skorları 8 ve 10 olarak değerlendirildi. Operasyon 35 dakika sürdü, herhangi bir problemle karşılaşılmadı ve toplam $800 \mathrm{~mL}$ kanama oldu.
Sezaryen öncesi tonik-klonik nöbet geçiren hipertansif hasta takip ve tedavi amacıyla yoğun bakıma alındı. Standart monitörizasyon yapılarak BIPAP modunda (FiO2:\%60, frekans 12/dakika, Pinsp: 25mbar) mekanik ventilatör (MV) ile solutuldu. NIKB 155/95 mm/Hg, kalp hızı 106 atım/ dakika, SpO2 \%98 olan hastada 2+ pretibial ödemi ve 300 $\mathrm{mg} / \mathrm{dL}$ proteinüri mevcuttu. MgSO4 infüzyonununa 24 saat devam edildi. Sedasyon amacıyla midazolam intravenöz infüzyonu başlandı ve NIKB 140/85 mm/Hg ile 130/80mm/ $\mathrm{Hg}$ arasında seyretti. Koagülasyon parametreleri, tam kan sayımı ve biyokimyasal değerleri normal olarak ölçüldü. 24 saatlik MV takibi sonrasında vital bulguları stabil seyreden hastanın sedasyonu kesildi ve yeterli spontan solunum ile sözel uyaranlara cevap alınınca ekstübe edildi.

Bilinci açık olan hastada her iki gözde görmenin olmadığı tespit edildi. Göz muayenesinde her iki optik disk ve makula normaldi ancak hasta ışığı fark edemiyor ve parmak sayamıyordu. Göz dibi muayenesinde papil ödemi olmadığı, ışık refleksinin iki taraflı alındığı ve görme kaybı dışındaki nörolojik muayenesinin normal olduğu görüldü.

Kraniyal patolojiyi değerlendirmek amacıyla bilgisayarlı tomografi (BT) ve manyetik rezonans (MR) çekildi. BT'de oksipital bölgede periventriküler alanda ödem ile uyumlu hipodens alanlar izlendi (Resim 1). MR'da oksipital bölgede flair sekansta sağda daha belirgin olmak üzere bilateral sinyal artışı görüldü (Resim 2).

Klinik ve radyolojik bulgular eşliğinde eklampsiye bağlı gelişen kortikal körlüğe neden olan posterior reversibl ensefalopati sendromu (PRES) düşünüldü. Hipertansiyonu kontrol altında olan hastaya $1000 \mathrm{mg} / \mathrm{gün}$ metil prednizolon başlandı ve kademeli olarak azaltılarak kesildi.

Görme kaybı 2. gün kısmen, 3. gün ise tamamen düzeldi.

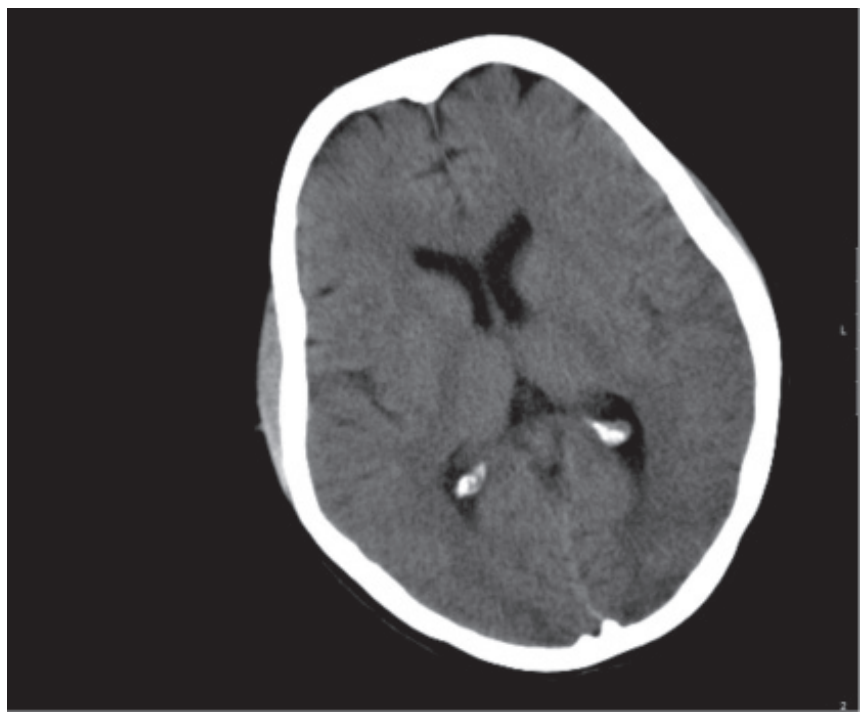

Resim 1. Oksipital bölgede periventriküler alanda ödem ile uyumlu hipodens alanların BT görüntüsü. 


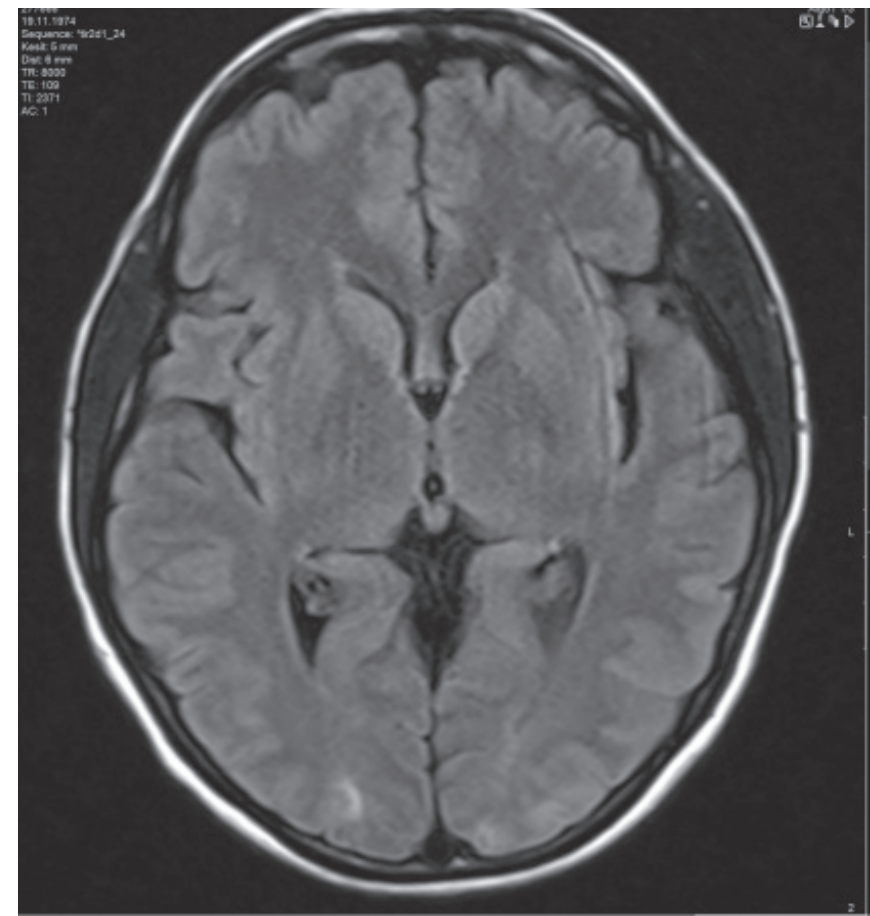

Resim 2. Oksipital bölgede flair sekansta sağda daha belirgin olmak üzere bilateral sinyal artışının MR görüntüsü

\section{Tartışma}

Gebelikte birçok organ etkilenebilir. Görme ile ilişkili fizyolojik değişiklikler; kornea hassasiyetinde azalma, kornea kalınlaşması ve eğriliğinde artış şeklindedir (5). Bu geçici değişikliklerle birlikte özellikle üçüncü trimesterde göz içi basıncında düşüş olmaktadır. Preeklampsi veya eklampsinin neden olduğu oftalmik bozukluklar; kortikal körlük, seröz retinal dekolman, Purtscher benzeri retinopati, santral retinal ven oklüzyonu, retinal veya vitreus kanaması şeklindedir ancak en sık bulgu retinal arteriyollerdeki daralma ile oluşur. Bulanık görme, çift görme, amarozis fugaks, fotopsi ve skotom gibi görme semptomları preeklampside \%25 ve eklampside \%19-45 arasında olduğu bildirilmektedir (1).

Ani görme kaybına neden olan kortikal körlük nadirdir ancak preeklampsi/eklampsilerde \%15 oranında görülmektedir. Normal pupil ve göz muayene bulgularıyla karakterize kortikal körlükte oksipital korteks etkilenmiştir. Doğumdan önce veya sonra görülebilir ancak doğumdan sonraki haftalarda görülmesi çok nadirdir. Körlük genellikle geri dönüşüm gösterir ve 4 ile 192 saat sürdüğü bildirilmiştir (7). Hastamızda ani görme kaybı sezaryenden sonra gelişti, göz ve pupil muayenesinde patoloji yoktu ve 24 saat içinde kısmen düzelirken, 72 saat içinde tamamen geçti.

Preeklampsi/eklampsiye bağlı gelişen kortikal körlük genellikle PRES ile ilişkilidir. PRES baş ağrısı, kusma, nöbet, mental durum değişikliği, görme bozukluğu ile vazojenik ödemin kraniyal görüntüsünü içeren klinik ve nöroradyolojik bir durumdur (1). Serebral otoregülasyonun kaybından kaynaklandığı düşünülmektedir. Posteriyor serebral arterin ani basınç değişikliğinden etkilenmesi ile oluşan vazojenik ödem, en sık posterior serebral dolaşım alanını etkiler (8). BT'de oksipital kortekste veya oksipital ve pariyetal kortekste düşük dansiteli lezyon görülebilir (9). MR'da ise yine aynı bölgelerde hiperintens lezyonlar izlenebilir. Hastamızda BT'de oksipital alanda periventriküler ödem ve MR'da aynı bölgede sağda daha belirgin olan bilateral sinyal artışı gösteren alanlar görüldü.

Sonuç olarak ani görme bozukluğu veya körlük önceden sağ|ıkı olan bir birey için oldukça korkutucu ve endişe vericidir. Neyse ki klinik (fetusun ve plesantanın doğurtulması gibi) ve laboratuar değerlerin düzeltilmesiyle günler içinde tamamen iyileşmektedir. Titiz bir öykü ile nörolojik ve oftalmik muayene, hasta ve yakınlarına pozitif destek ile güven verilmesi büyük önem taşımaktadır.

\section{Kaynaklar}

1. Roos NM, Wiegman MJ, Jansonius NM, Zeeman GG. Visual Disturbances in (Pre)eclampsia. Obstet Gynecol Surv 2012;67:242-50.

2. Steegers EA, von Dadelszen P, Duvekot JJ, Pijnenborg R. Pre-eclampsia. Lancet 2010;376:631-44

3. Cunningham FG, Leveno KJ, Bloom SL, et al. Pregnancy Hypertension. In: Cunningham FG, Leveno KJ, Bloom SL, et al., eds. Williams Obstetrics, 23e Ed. New York, NY: The McGraw-Hill Companies, Inc.; 2011.
4. Zeeman GG. Neurologic complications of pre-eclampsia. Semin Perinatol 2009;33:166-72.

5. Schultz KL, Birnbaum AD, Goldstein DA. Ocular disease in pregnancy. Curr Opin Ophthalmol 2005;16:308-14.

6. Moseman CP, Shelton S. Permanent blindness as a complication of pregnancy induced hypertension. Obstet Gynecol 2002;100:943-5.

7. Cunningham FG, Fernandez CO, Hernandez $\mathrm{C}$. Blindness associated with preeclampsia and eclampsia. Am J Obstet Gynecol 1995;172:1291-8.
8. Köken G, Yaman M, Yılmazer M, Oruç S. Ağır preellampside akut görme kaybı. Tıp Araştırmaları Derg 2007;5:36-8.

9. Adalı E, Kurdoglu M, Avcu S, Yıldızhan R, Adalı F, Kolusarı A. Reversible acute cortical blindness associated with eclampsia in complete hydatidiform mole. Ir J Med Sci 2011;180:287-90. 